\title{
Highly Efficient English MOOC Teaching Model Based on Frontline Education Analysis
}

\author{
https://doi.org/10.3991/ijet.v14.i06.10160 \\ Bo Gao \\ Jilin Institute of Chemical Technology, Jilin, China \\ 27811873 @qq. com
}

\begin{abstract}
The MOOC teaching model is a teaching method emerging with the rapid development of the Internet, characterized by openness, large scale, interactivity and feedback. However, at present, English is mostly taught in the traditional cramming model, which has such problems as fossilized teaching content, small corpus, single teaching method and lack of a feedback mechanism. Under this model, students lack the enthusiasm and initiative in English learning. By introducing MOOC, this paper innovates a new teaching model that combines the traditional English teaching model with the MOOC teaching resources. This model proves to be able to increase the classroom efficiency and students' enthusiasm and awareness of independent learning and also help significantly improve their abilities of reading, deep analysis, expression and cooperation. The introduction of the MOOC teaching model is an attempt in English teaching, which is in line with the contemporary education philosophy in this new era.
\end{abstract}

Keywords-MOOC model, English reading, frontline education, effect

\section{Introduction}

With the development of global economic integration, communication has become an essential ability, and language is one of the most important communication tools. As a universal language in the world, English has been widely used in all aspects of life and learning. However, the traditional cramming model is still very common in the front-line English teaching [1-3], making students less motivated in learning.

The rapid spread of the Internet has affected the direction of social life and economic development. Similarly, in the field of education, the Internet has also spawned an emerging teaching approach - MOOC [4-6]. To some extent, it breaks through the limitations of time and space, which is more conducive to the development of English teaching. Moreover, it can also concretize teaching theories, generalize teaching activities and make the teaching process more concise. Therefore, it is necessary to discuss the influences of MOOC on English frontline education and its applications.

At present, the research abroad mainly focuses on the theory, curriculum design and technical support. For example, Miranda et al. think that the MOOC model will be popularized with the development of social networks, and that it will become the 
preferred method for teaching communication, evaluation and feedback in the future [7-9]. The domestic educational circle has carried out relevant teaching practices and academic seminars [10-12] and established the MOOC platform, which has accumulated a large amount of quality education resources and so far achieved certain results.

In order to improve the efficiency of English teaching, change the traditional cramming teaching method and develop students' English reading and problem solving abilities, this paper analyzes the front-line English teaching and introduces the MOOC model into English teaching. Then it applies the new teaching model in a school to explore what influences and reform it can bring to the traditional English teaching.

\section{MOOC Education}

MOOC, i.e. massive open online courses, is the result of the rapid development of the Internet and computer industries. It is an emerging teaching method, with an open and personalized learning environment. In addition to the elements of the traditional classroom teaching, it also involves interactions with social tools. Therefore, MOOC education has obvious Internet thinking and characteristics, as shown in Table 1.

Table 1. Characteristics of MOOC Education

\begin{tabular}{|c|l|l|}
\hline Number & \multicolumn{1}{|c|}{ Characteristic } & \multicolumn{1}{c|}{ Meaning } \\
\hline 1 & Large scale & $\begin{array}{l}\text { The number of learners or the number of registered students in a course } \\
\text { will even reach tens of thousands of people. }\end{array}$ \\
\hline 2 & Online & $\begin{array}{l}\text { The learning process is implemented with the aid of Internet technology } \\
\text { and network environment, not limited by time and space. }\end{array}$ \\
\hline 3 & Openness & $\begin{array}{l}\text { The learning resources are completely free, achieving long-distance } \\
\text { knowledge sharing }\end{array}$ \\
\hline 4 & Curriculum resources & $\begin{array}{l}\text { The learning resources are self-contained and logical and have a complete } \\
\text { curriculum structure }\end{array}$ \\
\hline 5 & Feedback & Real-time feedback and interaction using networks \\
\hline
\end{tabular}

Table 2. Theories of the MOOC Education

\begin{tabular}{|l|l|l|l|}
\hline \multirow{5}{*}{$\begin{array}{l}\text { MOOC education } \\
\text { Meory }\end{array}$} & $\begin{array}{l}\text { Knowledge view } \\
\text { Constructivist } \\
\text { Learning Theory }\end{array}$ & Learning View & $\begin{array}{l}\text { Any symbolic system used to } \\
\text { carry and transmit knowledge } \\
\text { cannot completely convey the } \\
\text { absolute reality of the repre- } \\
\text { sentation. }\end{array}$ \\
\cline { 3 - 4 } & $\begin{array}{l}\text { Everyone understands the } \\
\text { world based on his own } \\
\text { experience and knowledge } \\
\text { structure }\end{array}$ \\
\cline { 2 - 4 } & Teaching view & $\begin{array}{l}\text { Emphasizing learners' initia- } \\
\text { tive and sociality and empha- } \\
\text { sizing situational and cooper- } \\
\text { ative language teaching }\end{array}$ \\
\cline { 2 - 4 } & $\begin{array}{l}\text { Humanistic Learn- } \\
\text { ing Theory }\end{array}$ & $\begin{array}{l}\text { Emphasizing students' learning needs and motivation and } \\
\text { paying attention to their learning attitudes and developing } \\
\text { their potentials. }\end{array}$ \\
\hline
\end{tabular}


In addition, MOOC education is mainly based on the constructivist learning theory and the humanistic learning theory. This kind of education pays attention to the comprehensive quality and personal experience of students. By creating learning situations, it develops students' potentials and achieve non-instructive teaching, as shown in Table 2.

\section{Problems in Frontline English Teaching}

At present, English teaching in China is mainly exam-oriented and neglects the training of English application skills and the transmission of English culture and values. In the frontline English teaching, there are problems like fossilized teaching content, small corpus, single teaching method and lack of a feedback mechanism. As a result, students lack enthusiasm and autonomy in learning English. The problems are listed in Table 3.

Table 3. Shortcomings of the front-line English teaching

\begin{tabular}{|c|l|l|}
\hline Number & \multicolumn{1}{|c|}{ Problems } & \multicolumn{1}{c|}{ Results } \\
\hline 1 & $\begin{array}{l}\text { Fossilized teaching } \\
\text { content }\end{array}$ & $\begin{array}{l}\text { Students are losing interest in English learning, and then lose } \\
\text { confidence and patience. }\end{array}$ \\
\hline 2 & Small corpus & $\begin{array}{l}\text { Understanding of relevant cultural background knowledge is } \\
\text { influenced by the way of thinking of mother tongue culture. }\end{array}$ \\
\hline 3 & Single teaching method & $\begin{array}{l}\text { Lack of flexibility, ignoring students'sensitivity, autonomy and } \\
\text { differences in learning }\end{array}$ \\
\hline 4 & $\begin{array}{l}\text { Lack of feedback } \\
\text { mechanism }\end{array}$ & $\begin{array}{l}\text { Long-term and systematic cultivation and accumulation are } \\
\text { needed, but few of them can achieve such ideal results. }\end{array}$ \\
\hline
\end{tabular}

Through a survey of the motivations and needs of the students at a school regarding English learning, it is found that most students are aware of the importance of English learning, but the current English learning environment and method limit their enthusiasm and confidence in learning, as shown in Table 4.

Table 4. A Survey of learning motivation and learning needs

\begin{tabular}{|c|l|l|}
\hline Category & Proportion & \multicolumn{1}{c|}{ Characteristics } \\
\hline 1 & $26.3 \%$ & $\begin{array}{l}\text { I hope I can get good results in exams, and I have a strong determina- } \\
\text { tion to study. }\end{array}$ \\
\hline 2 & $8.2 \%$ & $\begin{array}{l}\text { In order to go abroad for further study, I have some knowledge of } \\
\text { high-level English learning and related examinations. }\end{array}$ \\
\hline 3 & $55.7 \%$ & $\begin{array}{l}\text { I understand the importance of English learning, but have no confi- } \\
\text { dence in it without the language environment }\end{array}$ \\
\hline 4 & $9.8 \%$ & $\begin{array}{l}\text { I can never learn English well because it is too difficult. I have given it } \\
\text { up. }\end{array}$ \\
\hline
\end{tabular}

It can be seen from Table 4 that Category 1 and 2 students have a good learning attitude and a strong motivation, and only need to be given some guidance in learning methodology and planning; Category 3, who take up the largest proportion, lack clear goals and confidence, so it is necessary to improve their initiatives and confidence; 
Category 4 students are giving up, so it is necessary to give them more patient guidance and help them regain interest and confidence in English learning.

\section{$4 \quad$ Analysis of the Efficient English MOOC Teaching Model}

The author selected four parallel classes of a school as the subjects, with Class 1 and Class 2 (68 students in total) as the experimental class and Class 3 and Class 4 (77 in total) as the control ones. Through the questionnaire survey, the author compared and analyzed the English teaching model after the introduction of MOOC and summarized the application and influences of MOOC in frontline English education.

\subsection{Evaluation method}

In order to verify the results of the MOOC-based education, the author evaluated the learning effect through both formative and summative evaluation. The formative evaluation mainly focused on classroom performance, learning of MOOC resources and oral test, etc., accounting for $10 \%$ of the total score, and the summative evaluation was based on the final exam results, accounting for $90 \%$ of the total score.

\subsection{Effect analysis}

After the teaching practice, a questionnaire survey was conducted among the students in the experimental and control classes. The results are as follows:

- Considering the current teaching method, do you find it necessary to introduce the MOOC teaching resources?

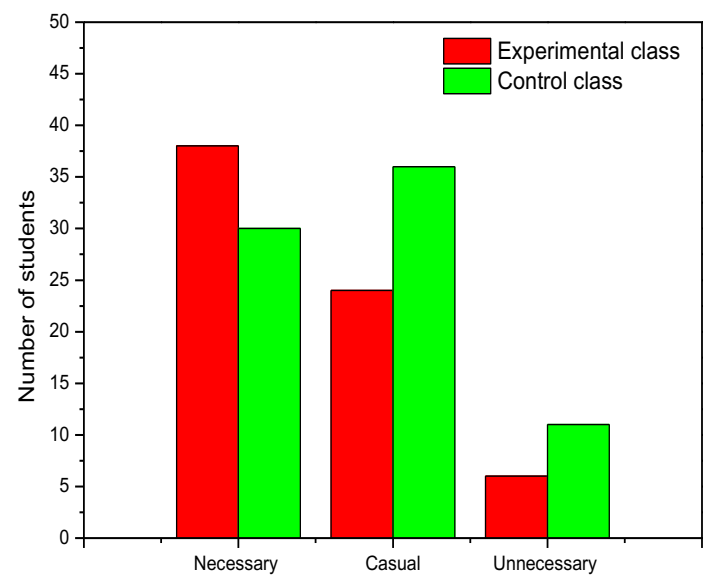

Fig. 1. Necessity of Introducing MOOC Teaching Resources 
As can be seen from Fig.1, most students were curious about the MOOC class and willing to accept new ways of learning.

- Do you find it helpful to watch the MOOC videos before each reading lesson?

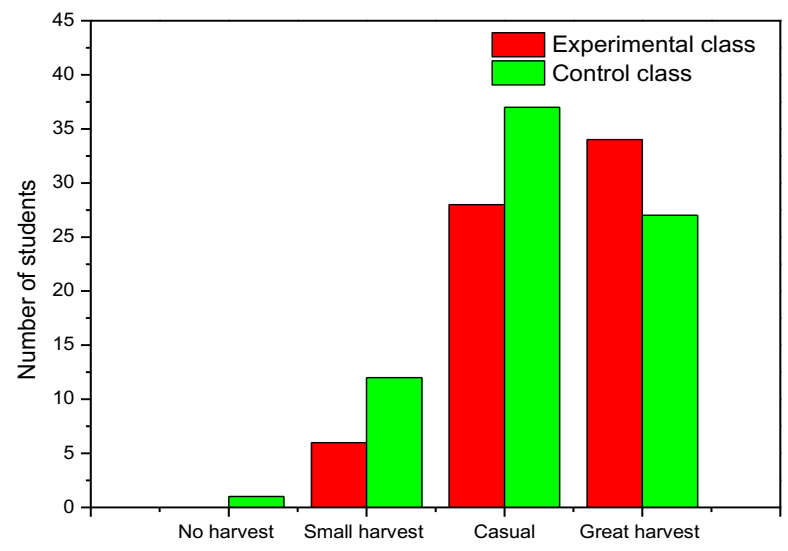

Fig. 2. Harvest of Watching MOOC Videos

As can be seen from Fig.2, most of the students believed watching MOOC videos was helpful to English learning, which provides a new way to improve English learning.

- What benefits do you think the teaching resources of MOOC brought you?

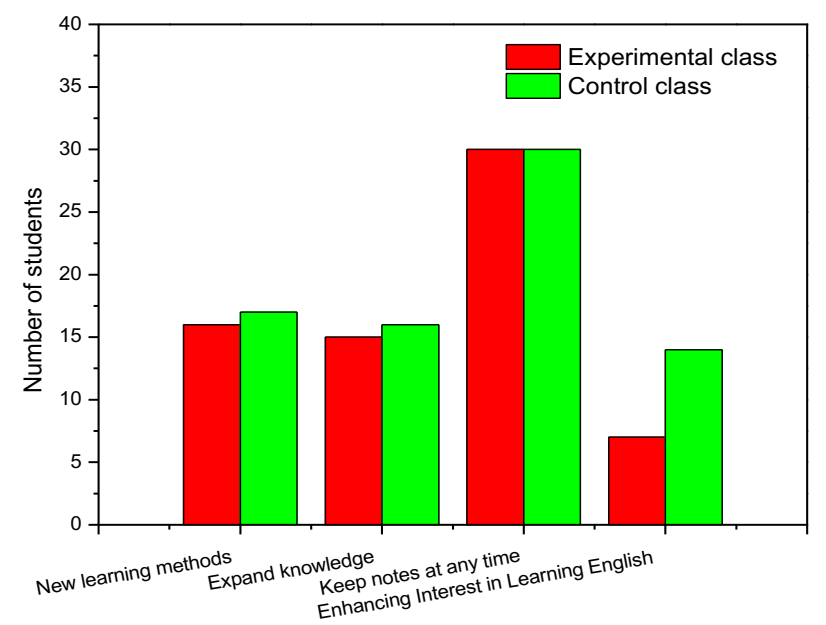

Fig. 3. Benefits of MOOC 
It can be seen from Fig. 3 that after the introduction of MOOC, students found new learning methods, expanded knowledge, and had more flexible time to learn and became more interested in English learning.

- How much time do you spend each day watching the MOOC videos?
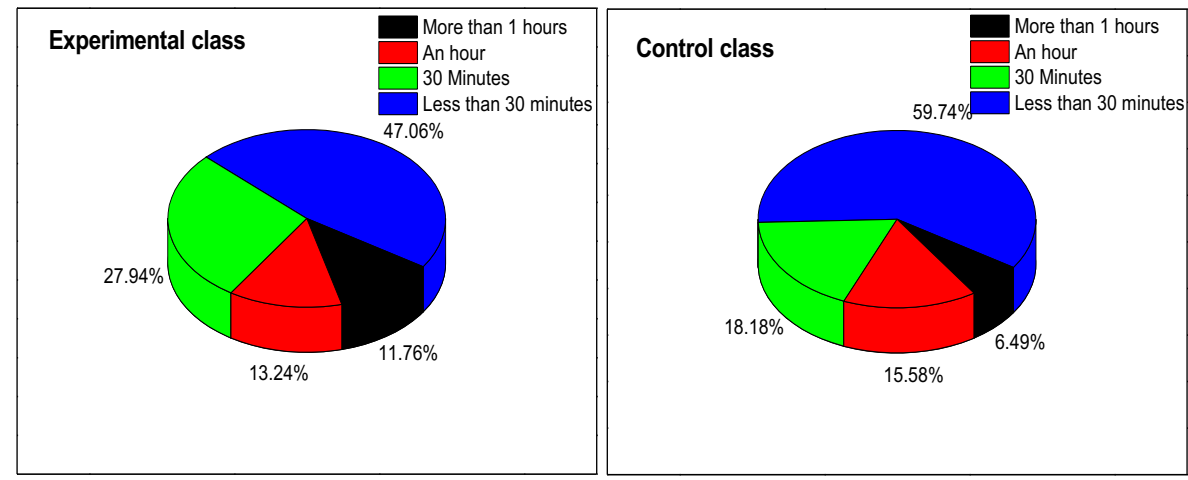

Fig. 4. Time spent watching the videos of MOOC

As can be seen from Fig. 4, students might forget what they learnt in class, but through the supplementary learning of MOOC, most students could revisit and understand the knowledge points learnt within 30 minutes.

- Currently, you improve your reading ability mainly through:

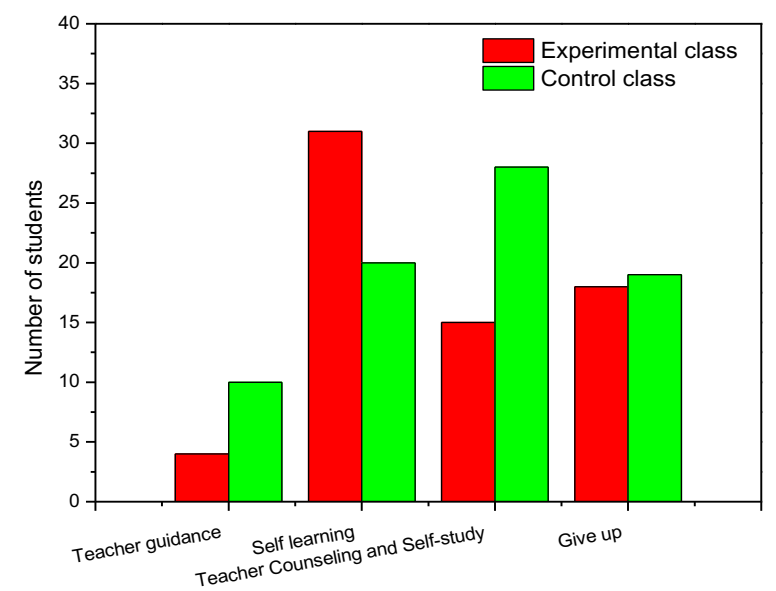

Fig. 5. Main Ways to Improve English Reading

As can be seen from Fig. 5, after the introduction of MOOC resources, nearly twothirds of the students in the experimental classes could learn independently under the 
guidance of the teacher and their English reading quantity was also increased; in the control classes, the students needed more assistance from the teacher.

Through comparison of the blended model with the traditional one, it can be found that the introduction of MOOC promoted the classroom atmosphere, enhanced the students' enthusiasm and interest in English learning and improved their independent learning abilities, as shown in Table 5.

Table 5. Comparison of the teaching effects between the two teaching models

\begin{tabular}{|l|l|l|}
\hline \multicolumn{1}{|c|}{ Experimental classes } & \multicolumn{1}{|c|}{ Control classes } \\
\hline Inquiry ability & $\begin{array}{l}\text { Students could ask questions and follow clues } \\
\text { and materials to find answers. }\end{array}$ & $\begin{array}{l}\text { Students found it difficult to find answers } \\
\text { and ask questions. }\end{array}$ \\
\hline $\begin{array}{l}\text { Cooperation } \\
\text { ability }\end{array}$ & $\begin{array}{l}\text { Students learnt to cooperate with others and } \\
\text { accomplished their learning tasks together. }\end{array}$ & $\begin{array}{l}\text { When facing learning tasks and prob- } \\
\text { lems, they were not good at asking for } \\
\text { help or helping their classmates. }\end{array}$ \\
\hline $\begin{array}{l}\text { Expressive } \\
\text { ability }\end{array}$ & $\begin{array}{l}\text { They were willing to put forward their own } \\
\text { questions and opinions by acting, talking and } \\
\text { giving speeches, etc. }\end{array}$ & $\begin{array}{l}\text { They answered teachers' questions } \\
\text { passively and seldom expressed them- } \\
\text { selves actively. }\end{array}$ \\
\hline Analytical ability & $\begin{array}{l}\text { They had the basic ability to analyze the genre } \\
\text { and structure of an article, and to discuss the } \\
\text { author's writing intentions and personal } \\
\text { impact. }\end{array}$ & $\begin{array}{l}\text { They passively waited for the teacher to } \\
\text { give answers and reading methods. }\end{array}$ \\
\hline
\end{tabular}

\subsection{Comparative analysis of results}

This paper selected the mid-term and final exam scores in two semesters as the comprehensive test results, as shown in Table 6.

Table 6. Comparison of the test results between the experimental classes and the control clas-

ses

\begin{tabular}{|c|l|c|c|c|c|}
\hline \multirow{2}{*}{ No. } & \multirow{2}{*}{ Semester } & \multicolumn{2}{|c|}{ Mid-term results } & \multicolumn{2}{c|}{ Final results } \\
\cline { 3 - 6 } & & $\begin{array}{c}\text { Experimental } \\
\text { classes }\end{array}$ & $\begin{array}{c}\text { Control clas- } \\
\text { ses }\end{array}$ & $\begin{array}{c}\text { Experimental clas- } \\
\text { ses }\end{array}$ & $\begin{array}{c}\text { Control clas- } \\
\text { ses }\end{array}$ \\
\hline 1 & First semester & 85.21 & 85.65 & 87.61 & 87.58 \\
\hline 2 & Second semester & 89.45 & 87.02 & 91.95 & 87.60 \\
\hline
\end{tabular}

From the above comparison, it can be seen that the experimental classes and the control ones had basically the same English level at the beginning. When the MOOC teaching model was introduced, the average score of the experimental classes was gradually improved - from 85.21 in the mid-term exam to 91.95 in the final exam, an increase of 6 points, while in the control classes, the average score was increased by only 2 points. In addition, according to the statistics of the test questions, it is found that the students in the experimental classes improved obviously in the reading comprehension and cloze parts, indicating that the MOOC teaching model has a significant effect in improving students' reading and analytical abilities. 


\section{Conclusion}

With the economic and social progress and fueled by the Internet technology, a new teaching method emerged - MOOC. Characterized by large scale, openness and interactivity, it forces the traditional teaching model to seek for reform to adapt to the new education philosophies and teaching needs. However, such new method also faces great challenges in its implementation. In order to study the role of MOOC in the English teaching model, this paper attempts to combine MOOC and the traditional model into a blended model in English teaching practice, and explores the feasibility of the MOOC teaching model in English learning through analysis.

- It combines MOOC teaching resources with the traditional English teaching model into a blended model and divides teaching into 3 organically connected parts - preclass, in-class and after-class, which provides a new idea for English teaching reform.

- The blended teaching model improves classroom efficiency and changes the leading role from the teacher to the students, which increases students' initiatives and awareness of independent learning.

- By analyzing the test results of the students in teaching practice, this paper finds out that the introduction of the MOOC teaching model can effectively improve their academic performance. In addition, their abilities of reading, deep analysis, expression and cooperation can also be significantly improved.

\section{References}

[1] Fox, A. (2013). From moocs to spocs. Communications of the Acm, 56(12): 38-40. https://doi.org/10.1145/2535918

[2] Mohammad Yusof, Y., Aliah Phang, F., Kashefi, H., Ismail, Z., Yusof, Y.M. (2012). Supporting engineering students' thinking and creative problem solving through blended learning. Procedia - Social and Behavioral Sciences, 56(56): 117-125. https://doi.org/10.1 016/j.sbspro.2012.09.638

[3] Plonsey, R. (2007). Bioelectricity: a quantitative approach. Springer New York, 38(2): 522-526. https://doi.org/10.1007/978-1-4757-3152-1

[4] Yeager, C., Hurleydasgupta, B., Bliss, C. A. (2013). Cmoocs and global learning: an authentic alternative. Journal of Asynchronous Learning Networks, 17(2): 133-147. https://doi.org/10.24059/olj.v17i2.347

[5] Bozkurt, A., Honeychurch, S., Caines, A., Bali, M., Koutropoulos, A., Cormier, D. (2016). Community tracking in a cmooc and nomadic learner behaviour identification on a connectivist rhizomatic learning network. Turkish Online Journal of Distance Education, 17(4): 4-30. https://doi.org/10.17718/tojde.09231

[6] O'Brien, K.L., Forte, M., Mackey, T.P., Jacobson, T.E. (2017). Metaliteracy as pedagogical framework for learner-centered design in three mooc platforms: connectivist, coursera and canvas. Open Praxis, 9(3): 267-286. https://doi.org/10.5944/openpraxis.9.3.553

[7] Miranda, P., Isaias, P., Pifano, S. (2015). Model for the evaluation of mooc platforms. Journal of Finance, 27(27): 765-77. https://doi.org/10.1111/j.1540-6261.1972.tb01310.x 
[8] Chen, G., Davis, D., Krause, M., Aivaloglou, E., Hauff, C., Houben, G.J. (2018). From learners to earners: enabling mooc learners to apply their skills and earn money in an online market place. IEEE Transactions on Learning Technologies, 11(2): 264-274. https://doi.org/10.1109/TLT.2016.2614302

[9] Seaton, D. T., Bergner, Y., Chuang, I., Mitros, P., Pritchard, D. E. (2014). Who does what in a massive open online course? Communications of the ACM, 57(4): 58-65. https://doi.org/10.1145/2500876

[10] De Langen, F., Herman, V.D.B. (2013). Massive open online courses: disruptive innovations or disturbing inventions? Open Learning: The Journal of Open, Distance and eLearning, 28(3): 216-226. https://doi.org/10.1080/02680513.2013.870882

[11] Suen, H.K. (2014). Peer assessment for massive open online courses (moocs). International Review of Research in Open \& Distance Learning, 15(3): 312-327. https://doi.org/10.1 9173/irrodl.v15i3.1680

[12] Clarke, T., Clarke, T. (2013). The advance of the moocs (massive open online courses). Education + Training, 55(4/5): 403-413. https://doi.org/10.1108/00400911311326036

\section{$7 \quad$ Author}

Bo Gao received her Bachelor of Arts Degree in 2004 from English major in the Jilin Normal University, Master of Arts Degree in 2011 from Linguistics and Applied Linguistics in Foreign Languages in Beihua University. Now she is an English teacher in Jilin Institute of Chemical Technology. Her main research interests include English Teaching Methodology and Sociolinguistics.

Article submitted 2019-01-16. Resubmitted 2019-02-27. Final acceptance 2019-02-28. Final version published as submitted by the authors. 